\title{
Multilateral Diplomacy
}

\begin{abstract}
Multilateral diplomacy has been central to the world order since World War II. Understanding how and why institutions and systems were established is essential to understanding where we have been and how to move forward in an increasingly shrinking world.
\end{abstract}

Multilateral diplomacy is a sunrise industry. The acceleration of globalization and the consequential shrinking of the globe has led to the literal, not metaphorical, creation of a global village. Every village needs its councils. All the processes of multilateral diplomacy serve to fulfill the functions of these global village councils. For the purposes of this chapter, 'multilateral diplomacy' will be defined as the practice of involving more than two nations or parties in achieving diplomatic solutions to supranational problems. As former UN Secretary-General Kofi Annan has said, 'diplomacy has expanded its remit, moving far beyond bilateral political relations between states into a multilateral, multifaceted enterprise encompassing almost every realm of human endeavor'. ${ }^{1}$ Several key themes will run through this chapter on multilateral diplomacy. One key theme is the theme of diversity. Since multilateral diplomacy is a rapid growth industry, new forms are emerging constantly, making it difficult to provide a comprehensive description of all types. A second key theme is a constant tension between justice and power in all the multilateral processes. In theory, multilateral diplomacy is guided by some key principles of the international order. Also, in theory, international organizations have been set up, by agreements reached in multilateral diplomacy, to perform certain functions and deliver certain global goods for the benefits of all-in other words, provide global governance in their relevant fields - and not to act as a means to the major powers' ends. In practice, however, power usually trumps principles and ideals. A third key theme is a tension

Originally published in Oxford Handbook of Modern Diplomacy, Apr 2013

1 'Address by Secretary-General Kofi Annan to the American Academy of Diplomacy upon receiving the Academy's "Excellence in Diplomacy" Award in Washington, DC, on November 28', United Nations Press Release, 30 November 2001. 
between universal organizations such as the United Nations which represent all of humanity and often enjoy great legitimacy, and several smaller and more informal groups or coalitions (like the G8 and G20) which also try to address key global challenges.

\section{Functions of Multilateral Diplomacy}

Multilateral diplomacy serves multiple functions. At the apex, it serves as the 'Parliament of Man'. The only way to find out what the 7 billion people of our planet think on any global challenge is to hear the voices of their national representatives in universal forums, like the UN General Assembly (UNGA) or universal conferences, like the Copenhagen conference on climate change. When disagreements surface, as they did at Copenhagen, they simultaneously reflect, like national parliaments do, the different views of the global population and can provide a safety valve.

A second, related function, especially for the 'Parliament of Man' after discerning the urgent needs of the global village, is to set aspirational goals for humanity. Hence, the UN Millennium Summit of 2000 set the Millennium Development Goals (MDGs) for 2015. Many MDGs will not be met but they have nonetheless inspired action on several fronts to improve the living conditions of the very poor on our planet. Without universal organizations like the UN, such agreements would be more difficult.

A third and also related function is norm creation. The world has essentially become a more civilized place since the Second World War through the steady accretion of civilizing norms. For example, the adoption of the Universal Declaration of Human Rights by UNGA in 1948 represented a great leap forward. It delegitimized heinous practices like slavery and torture. More recently the adoption by UNGA of two significant initiatives of banning landmines and cluster weapons indicate clearly how the norm creation function of multilateral diplomacy can serve to make the world a more civilized place. Similarly, UN conventions on children and women have significantly improved norms in these areas. Another significant breakthrough came when the UN Summit of 2005 endorsed the concept of 'Responsibility to Protect' (R2P). ${ }^{2}$ Of course, one central tension remains when creating norms within institutions such as the UN, where there still exists a contradiction between the sovereign members and the need to reach decisions that these sovereign members are compelled to follow. For the moment, the only way to handle this is through 'consensus'.

Multilateral diplomacy is also the means to negotiate international treaties that improve the state of the world. Two examples stand out. The Nuclear NonProliferation Treaty (NPT), adopted on 1 July 1968, in force since 5 March 1970, and renewed indefinitely on 11 May 1995, prohibits the development or transfer of nuclear weapons or related technologies by and to non-weapon holding states. The only non-signers today are Israel, India, and Pakistan. It has succeeded (with minor

${ }^{2}$ See chapter "Can the World Health Organization Be Rejuvenated?", this volume. 
exceptions) in preventing nuclear proliferation and delegitimized nuclear weapons. Sadly, the main violators of the NPT as a group have been the nuclear-weapon states, which have not moved quickly to fulfill their obligations to get rid of their horrific nuclear weapons. Similarly, the UN Convention on the Law of the Sea has created a common set of rules for the use of the world's oceans, which cover $70 \%$ of the earth's surface. The Convention, concluded in 1982, came into force in 1994 and 159 countries and the European Union have joined the treaty. The US, despite being one of the bigger beneficiaries of the treaty, has not ratified it, although it has largely adhered to its principles and rules.

All these processes of norm creation and treaty negotiation have served to lay down and strengthen international law. Just as the adherence to the rule of law domestically has generated social and political stability, greater adherence to international law has progressively reduced wars since the Second World War. Indeed the number of people dying from wars has reached historic lows. This one statistic alone should make the skeptics of multilateral diplomacy think twice before rubbishing it. Avoidance of war has improved the human condition.

Against this backdrop, the United States, the most powerful actor on the world stage, made a strategic error when it made a concerted effort to delegitimize UNGA as representing the voice of humanity. This decision was driven in part by the powerful pro-Israel lobby in Washington which was concerned over the anti-Israel resolutions passed by the UNGA. The American decision served neither the long-term interests of Israel nor those of the US. Indeed, the view advocated by the American right for the US to forget about the UN and work with the Community of Democracies was easily refuted by Anne-Marie Slaughter who pointed out that many of the opponents of the US war on Iraq belonged to this Community of Democracies. In short, a new American strategic approach is required if multilateral diplomacy is to serve well its key function as the 'Parliament of Man'.

In theory, UNGA also has a role to play in conflict resolution and peace-building. In practice, especially since the end of the cold war, the UN Security Council (UNSC) has played a key role in this area, but its record on this is chequered. While it solved many long-standing problems in Guatemala, Namibia, Cambodia, and the former Yugoslav Republic of Macedonia, and oversaw the inauguration of new national governments following the resolution of conflicts in El Salvador and Mozambique, the UNSC failed woefully in the Balkans, failed to prevent genocide in Rwanda, and has been remarkably ineffective on the Israel-Palestine issue.

Both problem-solving and furtherance of international cooperation is also carried out by the multilateral diplomacy processes of the many specialized agencies that have emerged since the Second World War (including the World Trade Organization (WTO), World Health Organization (WHO), International Atomic Energy Agency (IAEA), International Labour Organization (ILO), UN Environment Programme (UNEP), to mention only a few). Overall, the WTO and its predecessor, the General Agreement on Tariffs and Trade, have been spectacularly successful, with world trade growing three times faster than world output growth, from USD 296 billion in 1950 to over USD 8 trillion in 2005, thereby improving human welfare, increasing international interdependence, and creating a powerful vested interest in preserving 
global stability. Trade now accounts for almost one-fifth of the world's total GDP, up from only five percent in $1950 .^{3}$ Even though the latest Doha Development Round is in trouble, all the previous trading rounds succeeded even if the negotiations had been long and protracted. Equally importantly, there has also been no significant backsliding into trade protectionism, even in the world financial crisis of 2007-2009.

On a smaller scale, in terms of the number of countries involved in multilateral diplomacy but not in terms of impact, the G20 Summits of November 2008 and April 2009 played a critical role in saving the world from going over a financial precipice. ${ }^{4}$ These institutions and processors of multilateral diplomacy have so far passed the 'critical stress tests' surviving great crises, although of course the G20 could be made more inclusive, transparent, and participatory by periodic issue-wide inclusion of other stakeholders, as espoused by the 'Global Governance Group' in New York.

Kick-started by the global financial crisis, banking regulation will become an increasingly important challenge for ensuring the stability and sustainability of our world economic system; this is yet another area in which the tools of multilateral diplomacy can be put into action. The Basel Committee made up of representatives of all G20 major economies plus a few others, ${ }^{5}$ is a good example of multilateralism at work. Advocates of the second and third Basel Accords have called for the strengthening of international standards to reduce the risks faced by financial institutions, and for the creation of 'buffer' funds that will allow financial institutions to better withstand future periods of stress. Multilateral diplomacy enabled Basel to succeed.

The many and multiple functions performed by multilateral diplomacy demonstrate the importance of understanding how multilateral diplomacy works. More recently, this importance has been further demonstrated by how much of it is now done at the leaders' level. Leaders today consider it an essential part of their job description to travel overseas and attend summit meetings. By contrast, Sir Edward Gray never once traveled abroad during his long tenure as Britain's foreign secretary from 1905 to 1916 . How times have changed!

\section{Forms of Multilateral Diplomacy}

Multilateral meetings that take place in a year have taken on so many forms, and at so many different levels, that it would be difficult to measure all of them. However, even a cursory attempt at counting them will show that since the creation of the UN and

\footnotetext{
3 'World exports and world GDP, $1870<\mathrm{EN}>-2005$ ', World Trade Report 2007, World Trade Organization, 244. Available at: http://www.wto.org/english/res_e/booksp_e/anrep_e/wtr07-0b_e. pdf.

${ }^{4}$ See chapter "Diplomacy: Power or Persuasion", this volume.

${ }^{5}$ As of October 2010, members include: Argentina, Australia, Belgium, Brazil, Canada, China, France, Germany, Hong Kong SAR, India, Indonesia, Italy, Japan, Korea, Luxembourg, Mexico, the Netherlands, Russia, Saudi Arabia, Singapore, South Africa, Spain, Sweden, Switzerland, Turkey, the United Kingdom, and the United States.
} 
the Bretton Woods Institutions (BWI) in 1945, multilateral meetings have exploded, especially in the last two decades.

Any attempt to classify all the multilateral meetings will also face serious difficulties. Nevertheless, if one were to look for a few conceptual baskets to capture most of them, these conceptual baskets could be entitled as (1) universal, (2) functional/specialized, (3) regional, (4) ad hoc.

The creation of the UN and the BWI spawned the industry of universal gatherings and conferences which tried to get all of humanity represented. These universal gatherings have grown from the regular annual meetings of UNGA, the International Monetary Fund (IMF), and World Bank to now include all kinds of global conferences, from the UN Conference on the Law of the Sea to conferences on population, women, and the global environment.

After the failure of Copenhagen, there is now a new pessimism about the future of such global conferences. The new conventional wisdom is that such universal meetings are unworkable as they try to reconcile too many different interests. Yet, even in a small village, it would be folly to ignore the wishes of even a significant minority. True global solutions in a global village require the 'inclusion' of all members of the village in a solution. A dispassionate analysis of Copenhagen will show that it failed for many reasons, including the incompetence of the Danish chairmanship, the shift of power away from the West, the inability of President Barack Obama to persuade the US Congress to impose limits on American greenhouse gas emissions, and the need for China and India to maintain their economic growth rates to sustain their poverty alleviation efforts. In short, multilateral diplomacy exercises are inherently complex and success in them requires skillful leadership, like the kind provided by Ambassador Tommy Koh of Singapore when he ably steered the UN Convention of the Law of the Sea to a successful conclusion despite the many contradictions between groups like the 'Landlocked and Geographically Disadvantaged States' and the 'Continental Shelf' countries. Hence, when universal conferences fail, we should not blame the format. We should blame the lack of skill of the participants and the inherent contradictions of individual states' interests.

The UN family has also created a variety of specialized agencies with their own intergovernmental annual conferences and governing councils that provide direction and guidance on the basis of decisions reached through multilateral diplomacy. While some of their annual conferences and governing councils have also been derailed by political differences, which hamper the ability to provide good global leadership and governance in the respective fields, their track record shows that whenever a common danger is faced, the global community has been able to come together. This is especially true of the reaction to pandemics that do not respect national borders. Hence, it is useful to observe how multilateral diplomacy works well in specialized organizations like WHO to understand how humanity can come together and work together in universal multilateral conferences.

Multilateral diplomacy is growing very rapidly at the regional level. The most successful example of regional cooperation is provided by the European Union (EU). While most laud the economic achievements of the EU, its most striking achievement is not just that there are no wars, but that there is also zero prospect of war between 
any two EU member states. This is the gold standard of regional cooperation that all other regions should try to emulate. Sadly, no other region comes close.

Nevertheless, one untold story of the world has been how this European gold standard has gradually infected other regional organizations. I can speak with personal experience on what is possibly the second most successful regional organization, namely the Association of Southeast Asian Nations (ASEAN). When I first attended ASEAN meetings in the early 1970s, you could feel the distrust and suspicion among the five founding members. Yet two decades later, when I led the Singapore senior official delegation to ASEAN meetings, there was a much more relaxed and trusting atmosphere for concluding business. Two decades of regional multilateral diplomacy had changed the chemistry of ASEAN meetings and improved trust.

When people come together and interact frequently, over time, they develop a sense of community. This in turn reduces the prospects for conflict and enhances the prospects for cooperation. This is why after practicing multilateral diplomacy for over three decades in many different forums, universal and regional, I am a strong believer in its value. The fact that no two ASEAN states have gone to war with each other (despite some close shaves) since ASEAN's creation provides clear and powerful proof of the value of multilateral diplomacy.

Multilateral diplomacy at the regional level has also become a major sunrise industry. ASEAN, for example, has succeeded not just in enhancing cooperation between its ten members but also in providing an essential geopolitical platform for other Asian powers to meet and confer on neutral ground. It began with ASEAN inviting China, Japan, and Korea to join them at the famous ASEAN +3 meetings. These meetings demonstrated their value quickly. When bilateral relations worsened between China and Japan and their leaders could not meet bilaterally, they could meet each other without losing face in the multilateral setting provided by ASEAN +3 meetings. The meetings have now effectively expanded to ASEAN +8 with India, Australia, New Zealand, Russia, and the US joining the East Asia Summit meetings.

Relative to the EU, ASEAN is a latecomer. Hence, as the world moves ever more firmly into the Asian century, it would have been natural for the EU to undertake the bold initiative of proposing Asia-Europe cooperation. Instead, the EU remained passive and ASEAN took the lead. Prime Minister Goh Chok Tong of Singapore proposed an Asia-Europe Meeting (ASEM).

Fortunately, the EU embraced his proposal readily. I know this from firsthand experience as I traveled to several EU capitals to promote Prime Minister Goh's idea. The first ASEM Summit in Bangkok in March 1996 was an unqualified success. Unfortunately, the Asian Financial Crisis erupted soon after. This gave EU countries a valuable opportunity to demonstrate that they were not 'fair weather' friends of Asia. Sadly, the EU failed this test, demonstrating once again that European policymakers' judgments are clouded by short-term thinking. With the recovery of Asia, the ASEM process is back on track. Ironically, Europe got into trouble a decade later. Fortunately, the Asian states are showing wiser judgment by not walking away from Europe in its hour of travails. 
The success of multilateral diplomacy in Asia has profound implications for the global order as we move into a completely new era of world history marked by the end of Western domination and the return of Asia. It is vital to remember that from the year 1 to 1820, China and India consistently provided the world's largest economies. Hence, by 2050, when they return to their natural places in the global hierarchy of nations, the center of gravity of world history will also shift to Asia.

Therefore, what Asia does will drive world history. It would not have been inconceivable for the rising Asian powers to reject the Western-based principles that provided the foundations for the 1945 rules-based order created by the US and Europe. Fortunately, the rising Asian powers have decided to embrace rather than reject these Western principles. Ironically, the big question the world faces today is whether the Western states will respect their own principles of global order. Under international law, the use of force is justified only if it is an act of self-defense or authorized by the UN Security Council. The invasion of Iraq in March 2003 did not meet either criterion. Hence, as Kofi Annan declared, the Iraq war was illegal. ${ }^{6}$ If the Western states would like rising Asian powers to respect the key Western principles that underpin our global order, they must lead by example. This is why American attitudes toward multilateral diplomacy are critical.

The success of multilateral diplomacy is also demonstrated by the creation of various ad hoc diplomatic gatherings. The most famous and most powerful ad hoc group today is the G20. It saved the world from an economic meltdown in early 2009. Unlike established universal and regional groupings, like the UN or EU, the G20 has no headquarters or even rules of procedure. It is still truly ad hoc. But despite this, its ability to deliver results also shows the value of multilateral diplomacy. The success of a club is shown when outsiders clamor to get in and no insiders want to leave it. This is certainly true of the G20.

Other ad hoc forms of multilateral diplomacy have also emerged, with varying degrees of legitimacy and success. The initiatives against landmines and cluster bombs, despite initial opposition from established powers like the US, Russia, and China, found significant international momentum and were subsequently legitimized when both were endorsed by UNGA. A less successful example of ad hoc multilateral diplomacy is provided by the Proliferation Security Initiative (PSI) launched by the US. Its goal is to allow the interdiction of third-country ships suspected of carrying nuclear weapons in the high seas. Even though it has over 90 states supporting it, it is still opposed by several countries, including China which disputes its legality, and has therefore not yet been endorsed by the UN system.

\footnotetext{
${ }^{6}$ See for example, 'Iraq war illegal, says Annan', BBC News, 16 September 2004. Available at: http://news.bbc.co.uk/2/hi/3661134.stm.
} 


\section{Inherent Tensions of Multilateral Diplomacy}

International negotiations are supposedly conducted by reasonable men and women sitting around a table to arrive at a mutually beneficial agreement. This practice is deemed to be a significant advance in human civilization as we are seen to have moved away from the 'primitive' world when men made decisions by using their clubs and weapons, not reason. There is no doubt that the voice of 'Reason' has played a role in international negotiations and multilateral diplomacy.

My three decades of experience with multilateral diplomacy (in all its forms) have taught me that when I walk into a multilateral setting, I will encounter three voices: reason, power, and charm. The voice of charm has been underestimated. One simple story will illustrate how it works. In 1981 the UNSC was totally deadlocked over the selection of the next secretary-general. Fortunately, a young Ugandan diplomat (representing an extremely weak country just recovering from Idi Amin's excesses) named Olara Otunnu was elected as the president of the UNSC in December 1981. Using his charm and persuasiveness, he found a solution to the deadlock. Similarly, the legendary Singapore diplomat, Tommy Koh, was also able to use his considerable charm to persuade diplomats from over one hundred countries to agree to a solution in the law of the sea negotiations. Charm works in multilateral diplomacy as in other areas of life.

But neither reason nor charm can override the voice of power, which remains the single strongest factor in multilateral diplomacy and international relations. My two years in the UNSC in 2001-2002 taught me that we have not traveled far from the 'primitive' world order when brute strength and power drove human decisionmakings. The five permanent members (P5) would use the power of the veto formally and, more often, informally to distort the decision-making procedures of UNSC, with the result that instead of the UNSC fulfilling its charter obligations of 'preserving international peace and security', it was used to further the national interests and positions of the P5.

The biggest distortion has occurred on the Israel-Palestine issue. There is now a near-universal consensus in the international community that we need to have a twostate solution and that the forty-five-year illegal Israeli occupation of Palestinian land has to end. Any kind of global democratic voting will show there are over six billion people who will vote for a two-state solution. However, the views of six billion people are being thwarted by six million Israelis who have managed to dominate American decision making. This global distortion could ultimately lead to a long-term tragedy for Israel when the new correlation of forces begins to constrain American power significantly in the twenty-first century.

To rescue the UN and strengthen multilateral diplomacy, we have to quickly resolve the Israel-Palestinian issue because it has generated more international political poison than any other issue. It has caused the double delegitimization of the UN: delegitimization of the UN in the eyes of the American public because the American media has highlighted its anti-Israel positions in UNGA and delegitimization of the $\mathrm{UN}$ in the eyes of 1.6 billion Muslims who notice the pro-Israel positions of the 
UNSC. Hence, until the Israel-Palestine issue is resolved, the UN will be effectively crippled and multilateral diplomacy will be consequently constrained.

The insistence of the P5 in putting 'national interests' ahead of 'global interests' has led to many other distortions in UNSC decision making. The Clinton Administration blocked an effective international response to prevent genocide in Rwanda by refusing to allow the word 'genocide' in a UNSC resolution. Similarly, the Bush Administration distorted the role of the UNSC when it used its considerable 'unipolar' power to get the UNSC to go beyond its legitimate role and interfere in a 'judicial' decision by granting immunity to American troops from the International Criminal Court. Similarly, Russia prevented the UNSC from responding in Kosovo in 1999. Similar examples can be found for the other three permanent members.

Power, however, is not static. Having served as Singapore's ambassador to the UN in two different historical phases, I saw at first hand how multilateral diplomacy is conditioned by the international geopolitical order. In the mid-1980s, when the cold war was still on, the UNSC was paralyzed by the gridlock between the USA and USSR. Hence, UNGA was the main focus of attention. It performed creditably in condemning both the illegal Soviet invasion of Afghanistan and the illegal American invasion of Grenada. When I returned to the UN in 1998, UNGA was completely ignored and all the attention and focus was on the work of the UNSC.

Multilateral diplomacy is now going to face the biggest test of its ability to adapt to a new geopolitical order with the impending biggest shift of geopolitical power we have seen in several centuries. As indicated earlier, we are reaching the end of the era of Western domination of world history (but not, of course, the end of the West) and the return of Asian countries, especially China and India, to their natural position of providing the biggest economies of the world. There is no doubt that the world will have to make massive adjustments trends to adapt to the huge shifts in power. Multilateral diplomacy will have to do the same.

This will be an extremely complex and difficult exercise. In the current multilateral order, the language, concepts, and definitions of legitimate and illegitimate international behavior are primarily Western in origin. Indeed, today's international system of states, international organizations, and multinational corporations find its roots in the Peace of Westphalia, a treaty signed in 1648 between European rulers who sought to establish the territorial integrity of their states. Since the Treaty of Westphalia, there has not been an occasion when the international community adopted a different view from that of Westphalian state sovereignty and one of the greatest difficulties facing us today is a tension between individual state sovereignty and a need for global solutions to global problems. On the one hand, the United Nations is a collection of sovereign states, and its mission is, to some degree, to protect their sovereignty. On the other hand, global problems demand a united global strategy that may transcend individual states' sovereignty.

However, there have been minor but revolutionary changes. Consider, for example, the latest concept in international relations: the 'Responsibility to Protect' adopted by UNGA in 2005. In theory, this concept overrides national sovereignty. What the leaders agreed to in the outcome document was therefore a landmark decision for international law. The enormous importance of this decision has not quite sunk in 
yet but it will in time to come. This was the result of a Canadian initiative. Will such concepts be retained or rejected when the West no longer dominates the multilateral order?

One critical, underestimated problem here is that most Western policymakers and public intellectuals believe that the international behavior of most Western states has been 'responsible' and 'legitimate'. That is why American leaders can, with a straight face, call on China to emerge as a 'responsible stakeholder' in the international order. Yet, the West only provides less than $12 \%$ of the world population. A vast majority of the $88 \%$ of the world population who live outside of the West increasingly question the 'responsibility' and 'legitimacy' of the West as they are acutely aware of the duplicity and double standards prevalent in Western international behavior. The West must learn to listen to the voices of the majority of the world's population or else we may face sad consequences. The story of the invasion of Iraq shows what can go wrong when the West ignores global opinion.

This huge shift in global history could also provide multilateral diplomacy its biggest opportunity to demonstrate its new relevance. Its primary function, as indicated earlier, is to serve as the 'Parliament of Man'. Hence, instead of trying to delegitimize and derail UNGA, the Western powers, especially the US, should try to revive UNGA's early critical role in providing a forum for hearing the voices of the newly-active members of the global community. The strong speeches of India's Jawaharlal Nehru and Egypt's Gamel Abdel Nasser, Indonesia's Sukarno, and Cuba's Fidel Castro in the 1950s and 1960s provided the world an understanding of what the newly-independent nations aspired to immediately after Western decolonization.

Today, we are witnessing a similar reemergence of long-dormant civilizations and societies. New voices are emerging, by the billions. The world needs to find an arena to allow these voices to express themselves. Fortunately, we do not have to reinvent the wheel. UNGA already exists. However, in the complex new world order we have, UNGA must capture the complexity of this new world. In their introduction to this Handbook, Cooper, Heine, and Thakur highlight the new actors on the world stage. They quote appropriately Anne-Marie Slaughter, who says:

We envision getting not just a new group of states around a table, but also building networks, coalitions and partnerships of states and non-state actors to tackle specific problems... To do that, our diplomats are going to need to have skills that are closer to community organizing than traditional reporting and analysis. New connecting technologies will be vital tools in this kind of diplomacy. ${ }^{7}$

Hitherto, most of these non-state actors have been powerful Western NGOs (like Amnesty International or Greenpeace) or inspired by Western ideas (like the Club of Democracies). This traditional Western domination in the world of non-state actors is also coming to an end. This is why the story of the Turkish flotilla that attempted to reach Gaza in May 2010 provided a powerful harbinger of the world that is coming. Similarly, the pictures of young Chinese students in Western capitals demonstrating against the Western demonstrators who were blocking the passage of the Olympics

\footnotetext{
${ }^{7}$ In an interview with David Rothpokf, 'It's 3 a.m. Do you know where Hillary Clinton is?', Washington Post, 27 August 2009.
} 
torch showed that young people all over the world are becoming politically aroused. Given the huge demographic bulge of youth in the developing world, their voices must also be heard. The new UNGA must strive to become an accurate mirror of the views of 7 billion people on our planet.

The arrival of new non-state actors, however, does not mean that some of the previous traditional tensions have disappeared. The failure of the Copenhagen Conference in December 2009 provides a wonderful case study of what can go wrong in contemporary multilateral diplomacy. On the one hand, virtually all the NGOs in Copenhagen, both from the developing and developed countries, argued in favor of stronger global action against global warming. Their voices were best captured by the United Nations Intergovernmental Panel on Climate Change (IPCC), which, unlike Western NGOs, had a global collection of representatives. Yet, all their moral force failed against the traditional dynamic of negotiations among government representatives.

Obama's hands were tied when he arrived in Copenhagen because the US Congress refused to pass any legislation that would restrict American greenhouse gas emissions. If the then-largest emitter in the world would not cooperate, it was obviously absurd to expect the two new emerging powers, China and India, to make any compromises. The Indian PM, Manmohan Singh, put it well when he said he could not deprive the Indian people of electricity: 'Our energy needs are bound to grow. We will be failing in the duty to our nation and to posterity if we do not look ahead and take steps for not just today and tomorrow but for future generations. ${ }^{8}$ More than 400 million Indians lack electricity and supply falls short of peak demand by more than 16\%, according to the World Bank. At the end of the day, all the leaders, including Obama, Singh, Brazil's Luiz Lula da Silva, and China's Wen Jiabao, could not override their domestic national interests in favor of global interests.

The Copenhagen Conference also showed how a new geopolitical order was emerging. In the final meeting, the EU was not even represented in the room, showing what a geopolitical dwarf the EU had become. Apart from the US, China, and India were the key players. Despite their bilateral differences, China and India cooperated for a common cause. Brazil and South Africa also demonstrated the importance of newly-emerging economies. In short, a thorough case study of the Copenhagen Conference will draw out many lessons on the complexities of contemporary multilateral diplomacy. This conference also showed how urgently new thinking is needed if the world is going to succeed in global cooperation.

Fortunately, some failures of multilateral diplomacy at the global level are being compensated by successes at the regional level. In most regions of the world, regional cooperation is growing rather than receding. Apart from the well-known success stories of the EU and ASEAN, all regions see the value of working together. In most regions of the world (with the exception of South Asia which is bedeviled by India-Pakistan differences), intra-regional trade is growing. Intra-regional trade in East Asia, for example, accounted for only about $9 \%$ of trade in the whole region in 1990 . By 2010 it had grown to over $50 \%$, a spectacular increase by any measure.

8 'Nuclear energy essential for India: Manmohan Singh', Thaidian News, 24 March 2008. 
The volume of intra-regional trade in Africa has increased by almost $20 \%$ in the first decade of the twenty-first century and a similar story is true in Central and South America. However, even more, important than the economic benefits, the general decline of wars globally can also be attributed to greater regional cooperation.

Having participated in several meetings between ASEAN and EU officials, I have become acutely aware that the culture and mores of regional multilateral diplomacy vary significantly from region to region. In Europe, there is a strong legalistic emphasis with most of the time taken up by long arguments over the draft document. Success is measured by the quality of the written document. In East Asia, most of the focus is on building trust and understanding among the participants. The document is a secondary product. The more important result is the unspoken trust that has developed. I am deliberately exaggerating the differences to draw out the distinctions. But my experience with ASEAN and EU also taught me that new generations of multilateral diplomats must learn to develop deeper cultural sensitivities.

\section{Solutions}

Looking ahead at the future of multilateral diplomacy, it is clear that the world's leading policymakers, including key world leaders, face an acute dilemma in dealing with it. With the shrinking of the globe, the demand for multilateral diplomacy is likely to increase by leaps and bounds. On the other hand, as already mentioned, the supply of multilateral diplomacy is beset with many inherent problems. To resolve this dilemma the world needs to take a step-by-step approach to ensure that the processes of multilateral diplomacy will be available and at hand when the world turns to them to resolve acute global and regional problems.

The first step is to change our mindset about world order. We need to acknowledge that we live literally, not metaphorically, in a global village. Hence, right now, our primary global contradiction is painfully obvious: the biggest challenges of governance are global in origin, but all the politics that respond to them are local. There are many wise leaders around the world, but there is not enough global leadership.

The first decade of the twenty-first century has only accelerated the emergence of such global challenges. The era began with $9 / 11$ when a plot hatched by Osama bin Laden while living in Afghanistan brought down the Twin Towers in Manhattan. In 2003 SARS jumped simultaneously from a village in China to two cities on opposite sides of the world-Singapore and Toronto. Barely six years later, H1N1 haunted the globe. The speed and ferocity of the Lehman Brothers crisis brought the world to the brink of a meltdown.

The biggest challenge of all is progressing more slowly than the financial crisis. But climate change is the perfect example of just how ineffective our current leadership structures are. The solution to global warming is quite simple: we have to increase the economic price of greenhouse gas emissions equitably, with rich countries paying more and poorer nations paying less, but with all countries paying some price. Yet someone has to make the first move. America-whose population is only 
$5 \%$ of the world but consumes $25 \%$ of the world's gasoline-is the obvious candidate. If the price of a gallon of gasoline in the US were to be raised by one dollar (and that would still make an American gallon cheaper than a European or Singaporean gallon), the change in driving habits would dramatically cut emissions. And American leadership, by example, would likely change attitudes in other nations.

In many ways, the US is the wisest country in the world. It certainly remains the most successful, despite its recent travails. Yet in this land of wisdom and success, not one American politician would dare advocate a 'one dollar' solution to save the world. It would mean immediate political suicide. Herein lies the nub of the problem. Politicians are elected in local constituencies to take care of local concerns. Those who try to save the world will not last long.

This is why humanity needs a wake-up call. We can develop good domestic governance, from New Zealand to the Netherlands, Singapore, and Sweden. But good national leaders can only mitigate the shocks of global challenges, not solve them. Solutions have to be tackled through global organizations like the United Nations and the IMF, or global coalitions like the G20.

In theory, everyone agrees that we need to strengthen and open up these institutions. In practice, however, global organizations and coalitions are controlled by a few powerful national governments that put their interests ahead of the worlds. This is the ultimate global paradox. Great powers want to use their status to dominate global organizations - think of how the US and Europe still split the leadership of the World Bank and the IMF. But the more they control and distort the agenda of those institutions, the more they weaken them. And if these organizations are weak, solutions to global problems will simply not emerge.

The only way around this is to develop a strong, new international consensus, among citizens as well as governments, that the world needs more global governance (not global government). ${ }^{9}$ Only then will the mightiest nations think of the greater good and allow institutions - from the G20 to the UN, from the IMF to the WTO- to be revitalized. Indeed, a cooperative solution should provide each stakeholder with a better outcome than a solution reached by individual stakeholders. Yes, these bodies are imperfect. But in the world of politics, it is easier to reform existing institutions than to create perfect new ones.

The second step needs to be taken by the world's greatest power. Ever since the strong leadership of Dag Hammarskjöld (1953-1961), the US has decided (and during the cold war, in complete agreement with the Soviet Union) that its national interest was best served by a weaker UN leadership and weak processes of multilateral diplomacy. Hence, all international organizations, treaties, and laws were seen by American policymakers as constraints on American power. This policy may have made sense if America could have guaranteed that it would remain in perpetuity as the world's sole superpower (although I would argue that it would not have made sense even then). However, with China about to overtake the US as the world's greatest economic power shortly, it is timely for the US to reconsider its old policies

\footnotetext{
${ }^{9}$ See Weiss and Thakur (2010).
} 
of keeping multilateral institutions and processes weak. If America persists with these policies, there will be fewer constraints on China as it emerges as a great power.

Several beneficial practical consequences will emerge for multilateral diplomacy if the US decides to change its policy. First, the performance of international organizations would improve if the best possible candidates are chosen to run them rather than the weakest acceptable candidates. A UN, for example, with secretary-general of the caliber of a Kofi Annan rather than a Kurt Waldheim would be a more effective organization. A secretary-general with a strong moral voice would be perceived by the world as a secular Pope who could provide both moral and political leadership in bringing the world together to find strong collective solutions to the rapidly increasing 'global commons' problems we are facing. For this to happen, however, the P5, who wields the power to veto any candidate for the post, will need to overcome their desire to have more of a secretary than a general leading the UN bureaucracy. Indeed, even Kofi Annan was reported to have said that the ' $S$ ' and ' $G$ ' in his title stood for 'scapegoat' - a reference to the tendency of Western powers to blame the $\mathrm{UN}$ or its agencies for their own failures, making the UN the biggest convenient scapegoat.

Second, international organizations should be given the resources they need to meet growing global challenges in many areas. For example, the IAEA Commission of Eminent Persons, led by former President Ernesto Zedillo, recommended that the IAEA recruit and retain more nuclear-weapons inspectors in response to growing threats of non-proliferation. The US should go beyond lifting the Bush Administration's zero-growth budget policies toward international organizations to work with other developed partners to galvanize the necessary support for these organizations, all the while holding them accountable in terms of performance and efficient use of resources.

Third, the improved abilities, resources, and morale of international organizations would in turn increase their standing and prestige globally. The Western media, for example, would start looking to them for solutions to problems rather than portraying them as the problem. A reversal of the Western policy of delegitimizing international organizations would significantly improve their ability to perform better, which in turn would make multilateral diplomacy more attractive for capable young foreign service professionals. I can say this with great conviction because, as a young foreign service officer, I was actually discouraged from going into multilateral diplomacy. A senior Singaporean minister told me: 'Kishore, your job there is only to go to the UN and weep for the world. Don't expect to achieve anything concrete in the UN.' Equally, we should promote a balance between recruiting experts in areas such as finance or the global environment into the multilateral area, as well as encourage the brightest foreign service officers to take up global multilateral challenges.

My own life experience has taught me that the most successful organizations are those able to recruit the best and the brightest, whether the organization is Harvard or McKinsey, Bain or Goldman Sachs. Over the years, with the steady demoralization of most international organizations, fewer and fewer countries send their best diplomats to multilateral diplomacy. Instead, countries have sent their best diplomats to bilateral diplomacy. This has been a major strategic error as multilateral diplomacy has become 
more important for the world than bilateral diplomacy. Therefore, the branding and image of multilateral diplomacy must change in our brand-consumed world if it is to succeed in its mission.

It is vital to emphasize that different international organizations face different problems. The IMF and World Bank have been relatively well funded since they are profit-making institutions clearly controlled by the West. However, because they are perceived to be serving Western rather than global interests, their prestige, and standing, especially in Asia, diminished significantly after the Asian financial crisis. For the IMF and World Bank to remain relevant in the twenty-first century, the West must give up its controlling share of both organizations and allow their heads to be selected on merit rather than be the exclusive preserve of the US and Europe.

In short, multilateral diplomacy can be revived and strengthened with some clear practical steps including those mentioned in this chapter. However, these practical steps can only be taken after a new political consensus has emerged in key capitals, both in the established powers and in the newly-emerging powers, that the processes of multilateral diplomacy need to be strengthened, rather than weakened. The creation of this new political consensus will in turn require a concerted effort involving both key state and non-state actors.

\section{Reference}

Weiss TG, Thakur R (2010) Global governance and the UN: an unfinished journey. Indiana University Press, Bloomington

Open Access This chapter is licensed under the terms of the Creative Commons AttributionNonCommercial-NoDerivatives 4.0 International License (http://creativecommons.org/licenses/bync-nd/4.0/), which permits any noncommercial use, sharing, distribution and reproduction in any medium or format, as long as you give appropriate credit to the original author(s) and the source, provide a link to the Creative Commons license and indicate if you modified the licensed material. You do not have permission under this license to share adapted material derived from this chapter or parts of it.

The images or other third party material in this chapter are included in the chapter's Creative Commons license, unless indicated otherwise in a credit line to the material. If material is not included in the chapter's Creative Commons license and your intended use is not permitted by statutory regulation or exceeds the permitted use, you will need to obtain permission directly from the copyright holder.

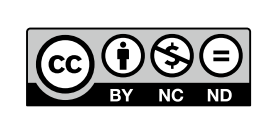

